УДК 398.91

\title{
Н.Н. Меньщакова
}

\section{ИСПАНСКИЕ ПАРЕМИИ СО СТЕРЖНЕВЫМ СЛОВОМ AJЕNO: ЛИНГВОКУЛЬТУРОЛОГИЧЕСКИЙИ АСПЕКТ}

В работе представлен результат лингвокультурологического анализа испанских паремий со стержневым словом ajeno. Благодаря своей синтактико-семантической структуре наиболее репрезентативным паремийным жанром в паремиологии считаются пословицы. На материале пословиц изучаются этнокультурное своеобразие языка, прагматический и функциональный потенциал паремий в речи, способ осмысления действительности, а также способ образования культурного смысла паремий. Анализируемые в работе испанские паремии, как правило, относятся к разряду пословиц. В ходе их анализа рассматриваются особенности сочетаемости лексемы ajeno со словами, с которыми это слово наиболее часто вступает в коллокацию: именем существительным, глаголом, местоимением в притяжательном падеже. Выявляются пословицы с бинарной оппозицией ajeno - propio, а также пословицы, в которых слово ajeno вступает в оппозицию с притяжательным местоимением или глаголом в форме первого лица множественного числа. Стержневое слово ајепо наиболее часто встречается в пословицах, чем другие его синонимы, например, слово extraño. Анализируются варианты пословиц, их различия, причины их существования. Логико-тематический анализ пословиц позволяет разбить их на шесть групп по выражаемой в них оценке или отношению к чужому. На этом основании делаются выводы о лингвокультурных особенностях паремий со стержневым словом ајепо.

Ключевые слова: паремиология, паремия, ајепо, испанский язык, лингвокультурология, фразеология, оценка.

DOI: $10.35634 / 2412-9534-2020-30-6-976-987$

\section{Введение}

В современной лингвистике паремии изучаются с разных точек зрения: фольклорной $[21 ; 24$; $41 ; 35]$, историко-этимологической [32; 28], диалектной [4;25; 34], логической [21], социолингвистической $[27 ; 37 ; 38]$, прагматической [23; 29], лингвокультурологической [11], аксиологической [2; 3 ; 13], дискурсивно-когнитивной [22; 26] и семиотической [1;2]. В паремиологии в разных языках до сих пор не решен однозначно вопрос об определении и разграничении некоторых видов паремий. Наиболее часто изучению подвергается пословичный жанр паремий. В русском языке слова «пословица» и «поговорка» в обыденной речи зачастую употребляются как синонимичные. В.М. Мокиенко в предисловии к «Большому словарю русских пословиц» [18], называет две наиболее распространенные трактовки пословиц в отечественной паремиологии: а) традиционную, принятую еще В.И. Далем [6], где пословица трактуется как краткое народное изречение законченного характера, а поговорка окольное выражение без заключения, первая часть пословицы; б) трактовку, принятую В.П. Жуковым [9] и его последователями, пословиц как синтаксически законченных народных изречений имеющих прямой и переносный смысл, а поговорок как народных изречений, обладающих только прямым смыслом. В американской паремиологии пословицы трактуются чрезвычайно широко, к ним относятся как традиционные пословицы, помещенные в словари пословиц, так и высказывания СМИ, фразы из популярных песен и фильмов, заголовки книг, рекламные слоганы, наклейки на бамперы машин, надписи на футболках, газетные заголовки, которые стали чрезвычайно популярными и частотными в речи и перешли в разряд современных пословиц [42]. В испанской паремиологии, несмотря на масштабные исследования в области формирования терминологического аппарата паремийных жанров [45], нет достаточно четкой дифференциации некоторых паремий, отраженной в словарях Королевской академии наук.

В традиционной интерпретации паремий основной функцией пословиц называется дидактическая [19;22], поскольку считается [6;18; 42], что в пословице содержится народная мудрость или совет, как нужно поступать в той или иной ситуации, хотя пословицы зачастую противоречат друг другу, так как отражают разные точки зрения на жизнь. Анализ пословиц связан с изучением культуры того народа, которому эти паремии принадлежат. В связи с этим в лингвистике проводится много исследований так называемых «пословичных картин мира», которые являются частью языковой картины мира, и репрезентируют видение мира сквозь призму пословиц. Пословичные картины мира раскрывают особенности мышления не только народа в целом [7], но и индивидуальный портрет челове- 
ка, употребляющего их в речи $[10 ; 15 ; 17 ; 20]$. Изучение культуры через язык происходит в рамках лингвокультурологии. Современная лингвокультурология занимается изучением концептов, и такие исследования относятся к сфере лингвоконцептологии [14. С. 933]. Лингвокультурологические исследования неразрывно связаны с аксиологией, поскольку картина мира, создаваемая языком, состоит из элементов, которые несут положительную или отрицательную оценку, а эта оценка, в свою очередь, может выражаться как имплицитно, так и эксплицитно $[40 ; 5 ; 8]$. Оценочность может изучаться как на уровне семантики или грамматики отдельного слова [16], так и на уровне законченного высказывания [29].

\section{Материал исследования}

Материалом исследования послужили испанские паремии, в состав которых входит стержневое слово «ајепо» («чужой», «чуждый»). В данной работе мы не дифференцировали паремии по национальным вариантам испанского языка, хотя такая дифференциация могла бы принести результаты, позволившие характеризовать особенности восприятия «чужого» представителями разных испаноязычных стран. Источником паремий послужили разнообразные интернет-ресурсы. Национальный корпус испанского языка [30] оказался, вопреки ожиданиям, не самым богатым источником материала. Бо́льшее количество паремий было найдено на платформе Centro Virtual Cervantes [44], предлагающей лексикографический многоязычный инструмент анализа паремий под названием Refranero Multilingüe, основанный на корпусе монолингвальных и полилингвальных словарей пословиц испанского языка. В библиографии этого ресурса фигурирует 34 испанских словаря паремий. Самым богатым источником материала для составления картотеки явился сайт [46], который предлагает более 30.000 пословиц и возможность поиска нужных пословиц по ключевым словам. Также на данном сайте имеются развернутые списки синонимов и антонимов (35.067 словарных статей), включающие наряду с собственно синонимами и антонимами псевдо-синонимы и псевдо-антонимы, т.е. слова, близкие по значению к синонимам и антонимам. Богатый материал представлен на сайте [47], разработанном Фернандо Мартинес дэ Карнеро, итальянским лингвистом-испанистом. На сайте дается более десятка лексикографических источников. Также использовался сайт с лингвистическими инструментами Refranero Castellano [48].

Общее количество выявленных паремий с опорным словом ајепо составило 229 единиц, включая паремические варианты (генетически связанные паремии со сходным смыслом, в которых изменен порядок слов или несколько отличается лексико-грамматический состав).

\section{Методы}

Анализ пословичной картины мира предполагает обращение к этнолингвистике и лингвокультурологии. Рассмотрение пословиц со стержневым словом ајепо предполагает, по сути, рассмотрение одного из этнических концептов испанского языка, и связано с кластерным анализом бинарной оппозиции «свой-чужой», в которой значительное внимание уделено элементу «чужой». Анализируемый материал позволяет создать некий речемыслительный «портрет предмета познания» (по Е. Бартминьскому) - пословиц со стержневым словом ајепо, которые отображают восприятие «чужого» испаноговорящими людьми. Выявленные признаки исследуемых паремий составляют профиль испанского этнокультурного сознания. В работе также используются такие общенаучные методы и методики как анализ, наблюдение, описание, интерпретация, лексикографический анализ, дефиниционный анализ.

\section{Основная часть}

Паремии традиционно изучаются в двух основных направлениях: «горизонтально», когда изучается семантика паремии в целом, и «вертикально», когда в центре внимания находится одно из стержневых слов паремии $[12 ; 26 ; 31 ; 36 ; 40]$. В данной работе мы рассматриваем пласт испанских паремий «вертикально», выбрав в качестве объекта исследования паремии со стержневым словом ajeno. Этот пласт паремий позволяет интерпретировать паремийный фрагмент концепта $A J E N O$ («чужое») в испаноязычной лингвокультуре, рассмотреть представления о чуждости, вербализованное в испанском языке словом ајепо. Рассмотрение данной группы паремий позволяет узнать, что именно носители испанского языка считают чужим, каково отношение людей к имуществу других людей, в какой мере чуждость, инаковость обладает негативной или положительной окраской. На 
значимость понятия чужого в паремиях обращал внимание еще Г.Л. Пермяков, когда, излагая концепцию логико-тематической классификации паремий, он довольно подробно описал группу «Свое или чужое?» в восточных языках [21. С. 24-29]. В. Мидер отмечает, что, несмотря на то, что народы Европы проживают рядом друг с другом, они очень многим отличаются и имеют очень разное, порой негативное отношение друг к другу. Это отношение выражается в пословицах. Так, например, в Америке во времена колонизации бытовала пословица “The only good Indian is a dead Indian”, в которой нашло отражение отношение американцев к коренным жителям континента [43. C. 15-24].

Анализ паремий с лексемой ајепо позволяет узнать, что именно традиционно представляется как чужое или чуждое в испанской лингвокультуре. Лексема ajeno не обладает в испанском языке однозначной положительной или отрицательной оценкой, которой обладают слова с прототипической прагматической оценочностью - прилагательные со значением «плохой», «хороший» и т.д. [29. C. 148]. Тем не менее, нам представляется, что анализ паремий с данной лексемой в качестве стержневого компонента позволит выявить аксиологические характеристики понятия, репрезентированного данной лексемой, и составить более четкое представление об одном из важных фрагментов языковой картины мира носителей испанского языка.

В словаре Королевской академии наук Испании прилагательное ајепо определяется следующим образом: 1) perteneciente a otra persona; 2) de otra clase o condición; 3) impropio, extraño, no correspondiente; 4) que no tiene conocimiento de algo, o no está prevenido de lo que ha de suceder; 5) distante, lejano, libre de algo [49].

У данного слова имеется ряд синонимов и антонимов, в том числе слов, семантически близких к ним. Синонимы слова ајепо: distante, lejano; indiferente, desinteresado; impropio, extraño; ignorante, desconocedor; externo; foráneo, forastero, extraño; diferente, distinto; absorto, abstraído, distraído, ausente, pensativo, concentrado [51]. Итого 20 синонимов и 8 смысловых групп. Антонимы ajeno (прил., сущ.): propio, sabedor, conocedor [50]. Кроме того, у слова ajeno имеются квази-антоним ы, т.е. семантически противопоставленные ему слова: personal, particular, perteneciente, característico, peculiar, singular, típico, específico, privativo, inherente, definitorio, correspondiente, mismo, apropiado, adecuado, conveniente, oportuno, correcto, decente, enterado, entendido, especialista, informado [46].

Слово ajeno относится к категории прилагательного и в словаре Королевской академии дефиниции ему даются именно как прилагательному. Однако в испанском языке прилагательное может субстантивироваться при помощи артикля lo. Поэтому в исследуемых нами паремиях слово ajeno принадлежит к категориям как прилагательного, так и существительного. В картотеке паремий со стержневым словом ajeno, имя прилагательное незначительно превалирует над существительным [49].

Приведем результаты анализа сочетаемости лексемы ајепо в картотеке собранных нами паремий.

Сочетания прилагательного ајеnо с существительными: pan (10), mal (9), bien (4), corral (3), caballo (2), ojo (2), cuidado (2), oficio (2), bolsillo (2), lecho (2), dejesa (1), gallinero (1), rebaño (1), pueblo (1), barrio (1), hogar (1), hombre (1), hecho (1), pleitos (1), talento (1), peligro (1), dolor (1), vientre (1), orgullo (1), trabajo (1), duelo (1), pesar (1), perro (1), dinero (1), vencimiento (1), cuero (1), seno (1), nido (1), pedo (1), sombrero (1), vino (1), dueño (1), heredero (1), paño (1), mercado (1), fruto del árbol (1), hijo (1), muerte (1), mesa (1), casa (1), tabaco (1), hado (1), soto (1), fuego (1). Итого, 49 имён существительных.

Сочетания субстантивированного прилагательного ајепо с глаголами: ser (2), callar (2), curar (2), repartir (2), pisar (1), llorar al (1), decir (1), juzgar a (1), criticar a (1), clamar (1), hacer (2), tener (1), guardar (1), dejar (1), vestirse de (1), desear (1), honrar con (1), perder (1), respetar (1), tomar (1), ambicionar (1), clamar (1), querer (1), penar por (1), ganar (1), comprar con (1), ver (1), quitar (1), ganar (1), usurpar (1), piar (1). Итого, 31 глагол.

Более высокая частотность сочетаемости лексемы ајепо с именами существительными явилось ожидаемым результатом, поскольку имя прилагательное выступает в роли определения имени существительного. Кроме того, необходимо отметить разнообразие существительных, которые вступают в отношения с прилагательным ајепо в анализируемых паремиях. Они варьируются от абстрактных и негативно окрашенных mal, dolor, muerte, orgullo, до возвышенных и положительно окрашенных bien, vencimiento, talento, hogar и др., до конкретных существительных с положительной - pan, trabajo и др. - и отрицательной окраской (сниженный регистр) - pedo.

В испанском языке много паремий, связанных с хлебом (например: contigo, pan y cebolla «с милым рай и в шалаше», pan agradecido «человек, помнящий добро», mas bueno que el pan «добрейший человек, душа человек», pan de Dios «добряк, добрая душа, святая простота», miga de pan «добряк, 
добрая душа, душа человек», como un cacho de pan «добрый, мягкий, уступчивый», и т.д.) и это находит отражение в полученных результатах: слово pan чаще всего сочетается с лексемой ајепо. При этом чужому хлебу дается практически однозначная оценка - отрицательная: чужой хлеб не мягок, не сытен, не вкусен (El pan ajeno hace al hijo bueno [46]. Pan ajeno nunca es tierno [46]. Pan ajeno, nunca sabroso ni tierno [46]. Pan ajeno caro cuesta [44]. Pan ajeno nunca es tierno [46]. Pan ajeno poco engorda [46]. Pan ajeno quita deseo [46]. Dar santo y bueno, pero del pan ajeno [46]).

В целом, чаще всего чужим в корпусе всех изучаемых пословиц называется либо некое материальное имущество, принадлежащее другим людям, деньги, блага, пища, либо нечто абстрактное, нематериальное, типа бед, забот, боли, болезни. И те, и другие оцениваются в пословицах по-разному, и как нечто хорошее, полезное, благое, и как плохое, жестокое. Многие паремии представляют собой простую сентенцию, не дающую оценки, что позволяет интерпретировать ее подходящим для конкретной ситуации образом.

Слово ajeno в паремиях также определяет существительные, обозначающие человека, но гораздо реже. В пословицах встречаются сочетания dueño del ajeno, heredero de lo ajeno, а также hijo ajeno. Если первые два сочетания говорят о принадлежности неких материальных благ или ценностей человеку, то в последней речь идет о «чужеродности», «чуждости» самого человека: Hijo ajeno, brasa en el seno [47]. Brasa trae en el seno, la que cría hijo ajeno [47]. No críes hijo ajeno, no sabes si te saldrá bueno [47]. Чужой сын, таким образом, представляется как потенциальный источник зла, проблем, неприятностей.

Ajeno в качестве субстантивированного существительного сочетается в изучаемых паремиях с меньшим, по сравнению с существительными, количеством глаголов и зачастую вовлекает в синтаксическую структуру предлоги. Например: Lo ajeno clama por su dueño [46]. Repartiendo de lo ajeno, ninguno es cicatero [46]. Asi usa lo tuyo, que no cures de lo ajeno [46]. Lo ajeno siempre píe por su dueño [47]. Кроме того, в ряде паремий субстантивированное прилагательное ајепо употребляется независимо от глагола или существительного. Например: De lo propio, se da un puñado, de lo ajeno, llena el saco [46]. De lo ajeno, gastar sin miedo, de lo propio, poquito a poco [46]. Todos son generosos con lo ajeno [46]. Lleno y ajeno, dos veces bueno [46]. Nada tan bueno, como lo ajeno [46].

Также субстантивированное прилагательное ајепо сочетается с неопределенными местоимениями algo (1), mucho (1) и todo (1): Algo ajeno no hace heredero [46]. Lo mucho ajeno ten en poco, y lo poco tuyo, en mucho [46]. Todo lo ajeno parece bueno, menos el hombre ajeno sobre la mujer propia [46]. Эти примеры демонстрируют, что чужое имеет собирательное значение и зачастую не важно, какой именно объект характеризуется при помощи слова ајепо.

Среди анализируемых паремий встретились несколько таких, которые имеют много вариантов с измененным порядком слов и заменой некоторых слов. При подсчете частотности сочетаний лексемы ајепо с именами существительными, глаголами и местоимениями варианты паремий не учитывались. Можно предположить, что факт наличия нескольких зафиксированных вариантов этих паремий говорит об их высокой частотности и употребляемости в речи.

Первая группа подобных паремий относится к разряду пословиц (refrán) и обладает всеми присущими им качествами - двусоставная синтаксическая структура, рифма, поучительная сентенция: Quien da pan a perro ajeno, pierde el pan y pierde el perro [44] / Quien da pan a perro ajeno, pierde pan y pierde perro [46] / Si das pan a perro ajeno, perderás pan y perderás perro [46] / El que da pan a perro ajeno, pierde el pan, pierde el perro y la amistad de su dueño [46] / Ver la mota en el ojo ajeno y no la viga en el nuestro [47]. Предлагаемые варианты отличаются наличием / отсутствием артиклей, сменой наклонения, а также добавлением части фразы, отсутствующей во всех прочих вариантах. В данной пословице говорится о том, что если вы подкармливаете чужого пса, то теряете хлеб, которым его кормите, но не завоевываете и преданности пса (теряете этого пса), да к тому же можете потерять и друга, хозяина этого пса. Словосочетание perro ajeno, таким образом, подразумевает, что пес не является вашей собственностью, не принадлежит вам. В данном случае слово ајепо не обладает ярко выраженной положительной или отрицательной оценкой.

Вторая группа паремий относится к библейским афоризмам (proverbios bíblicos) и известна во многих языках: Ver la paja en el ojo ajeno y no una viga en el propio [46] / El que vee la mota en el ojo ajeno, vea la viga en el suyo [48] / Se ve la paja en el ojo ajeno y no se ve la viga en el propio [46] / Vemos la paja en el ojo ajeno, y no vemos la viga en el nuestro [44] / Tú miras la paja del ojo ajeno, pero no al roble que tienes encima [46] - (Видеть сучок в глазу другого, а бревна в своем не замечать). В сочетании ојо ајепо просматривается определенная оценочная противопоставленность «я» - «другой». Рас- 
сматриваемая паремия дает имплицитную оценку неправильности осуждения других людей, тем самым можно заключить, что ajeno также обладает негативной окраской. В имеющихся вариантах различаются видовые формы смыслового глагола, порядок слов и наклонение глаголов, а также используются существительные, семантически близкие друг другу в контексте, но не синонимичные (viga и roble). То же самое относится к другой паремии: Al que de ajeno se viste, en la calle le desnudan [46] Al que de ajeno se viste, en la calle lo desnudan [46] / A quien de ajeno se viste, bien pronto lo desvisten [46] / A quien se viste de lo ajeno, le desnudan en concejo [46] / Quien de ajeno se viste, en la calle le desnudan [44] / Quien se viste de lo ajeno, en la calle lo desvisten [48] Quien con lo ajeno se viste, en la calle lo desnudan [47]. Здесь, помимо очевидных синтаксических изменений наблюдаются лексические замены: desnudan - desvisten, en la calle - en concejo, которые не меняют смысла пословицы. Еще один пример паремии с вариантом: El que a pueblo ajeno va a casar, o va engañado o va a engañar [46]. El que a pueblo ajeno va a pretender, o va a dar perro o a que se lo den [48]. Вторая часть пословицы у данных вариантов полностью различается, хотя смысл они имеют похожий. Скорее всего, в данном случае мы имеем дело с трансформантом, т.е. более современным вариантом пословицы, адаптированным к современным реалиям. Словосочетание pueblo ajeno здесь воспринимается нейтрально, в пословице звучит предостережение, но нет угрозы, поэтому «чужая деревня» есть неизвестная территория, правил поведения в которой мы не знаем.

Зачастую пословицы, обладающие компонентом с прагматической оценочностью, содержат контекстуальный антоним этого слова. В анализируемых паремиях со стержневым словом ајепо также имеются семантические противопоставления. Они встречаются в около трети всех паремий в нашей картотеке. Наиболее частотным является прилагательное propio («собственный»), которое, как было показано выше, является прямым антонимом слова ајепо. В 16 паремиях слово propio присутствует наряду со словом ајепо, выражая противоречие в семантике паремии. Рассмотрим некоторые примеры: Hogar ajeno suele criticar quien el propio no sabe arreglar [46]. Todo lo ajeno parece bueno, menos el hombre ajeno sobre la mujer propia [46]. Ver la paja en el ojo ajeno y no una viga en el propio [46]. Mayor vencimiento es el propio que el ajeno [46]. De lo ajeno, gastar sin miedo, de lo propio, poquito a росо [46]. В данных паремиях слово propio обладает значением «que pertenece de manera exclisuva a alguien» [49] и, таким образом, противопоставляется значению слова ajeno «рerteneciente a otra persona» [49]. В других паремиях propio употребляется в значении «conveniente, adecuado» [49], несмотря на то, что значение ajeno остаётся тем же: A caballo ajeno, espuelas propias [46].

Помимо лексического антонима в паремиях слово ајепо противопоставляется притяжательным местоимениям-прилагательным su (13), tu (4), mi (3), nuestro (2) и притяжательным местоимениямсуществительным suyo (10), tuyo (8), mío (2), nuestro (1).

Cada uno con su duelo no se cuida del ajeno [46].

Escucha al agujero y oirás tu mal y del ajeno [44].

Pan de trigo o centeno, mejor en mí vientre, que en el ajeno [46].

Mal ajeno, para el nuestro no es consuelo [46].

Quien dice lo suyo, mal callará lo ajeno [46].

Asno lerdo, tú dirás lo tuyo y después lo ajeno [46].

El mal ajeno no cura el mío [46].

Nosotros a lo ajeno y el diablo a lo nuestro [46].

Семантическое противопоставление также может проявляться в грамматической форме глаголов, употребляемых в паремии. Например, в пословице Todos somos rápidos para repartir lo ajeno [48] форма 1 лица мн.ч. глагола ser противопоставляет чужое нашему: ajeno и nosotros («мы»). А в паремии Todos son generosos con lo ajeno [46] чужое представляется таковым по отношению к людям вообще, поскольку глагол ser употребляется в 3 лице мн.ч., которое используется для обозначения безличного или неизвестного субъекта. Подобные оппозиции «свой-чужой» являются очень показательными, именно в них выявляется крайне пренебрежительное отношение людей к «не своему», будь то горе, чужой секрет, или хлеб насущный. В них также прослеживается мысль о том, что своё нужно беречь, чтобы оно не стало чужим (не стало достоянием общественности) Asno lerdo, tú dirás lo tuyo y después lo ajeno [46], или не досталось недругам (Nosotros a lo ajeno y el diablo a lo nuestro [46].

Следуя логико-тематической классификации паремий Г.Л. Пермякова [21], мы разделили все выявленные паремии со стержневым словом ајепо на несколько групп, согласно их семантике. Наиболее многочисленная группа (I) паремий со стержневым словом ајепо объединена семой «нечто ма- 
териальное, принадлежащее другому человеку». В эту группу включены паремии, отображающие отношение людей к чужой собственности: вещам, пище, животным, дому: Quien da pan a perro ajeno, pierde el pan y pierde el perro [46]. El dinero del juego, tan pronto es mío como ajeno [46]. Caballo ajeno no cansa nalgas [46]. Lo ajeno no tiene heredero [46]. В них просматривается желание человека обладать чужим имуществом, зависть, грусть, что оно принадлежит кому-то еще.

Следующая группа (II) паремий объединена семой «нематериальное не моё, а ближнего моего»; в нее включены паремии, в которых чужими называются секреты, боль, голод, порок, талант, гордость, и т.д.: Vientre lleno, no cura el ajeno [46]. El dolor que mejor se soporta, es el dolor ajeno [46]. Al juzgar un hecho ajeno, mete la mano en tu seno [46]. Escucha al agujero y oirás tu mal y del ajeno [44]. Asno lerdo, dirá lo suyo y lo ajeno [46]. Mal ajeno es ruin consuelo [46]. Mal ajeno no cura mi duelo [46]. Pesar ajeno, no quita el sueño [46]. В данных паремиях ajeno подразумевает нечто абстрактное, отдаленное от человека. В большинстве паремий этой группы отражается нежелание людей иметь что-то общее с чужими горестями или печалями, либо безразличие к ним.

Следующая группа (III) объединена семой «на не своей / на чужой территории». Входящие в нее паремии выражают идею о том, что чужая территория неуютна, находиться на ней опасно, сложно и глупо: Asno que entra en dejesa ajena, volverá cargado de leña [48]. Gallo que es bueno, lo mismo canta en su corral que en el ajeno [46]. Estoy como gallo en corral ajeno [46]. No cacarees en corral ajeno [46]. El que a pueblo ajeno va a casar, o va engañado o va a engañar [46]. Tienes en casa el muerto y vas a llorar al ajeno [46].

Следующая (IV) группа паремий обладает семой «не свой, незнакомый, неизвестный». В ней реализуется отличающееся от предыдущих значение слова ајепо, которое раскрывает неизвестную и инородную природу объекта высказывания: A caballo ajeno, espuelas propias [46]. A pan ajeno, navaja propia [46]. A caballo ajeno primero la silla y después el freno [46]. El amo bueno no debe fiarse del ojo ajeno [48]. El asno bueno, no se debe fiar del ojo ajeno [48]. Todo lo ajeno parece bueno, menos el hombre ajeno sobre la mujer propia [47]. В этих паремиях звучит предостережение, совет быть осторожным и осмотрительным с тем, что непривычно, инаково.

Следующая (V) группа паремий имеет сему «не свое и чуждое, враждебное». В ней объединяются паремии, в которых выражается однозначное толкование пагубности чужого имущества для жизни человека: Pan ajeno nunca es tierno [46]. Pan ajeno poco engorda [46]. Pan ajeno quita deseo [46]. Dar santo y bueno, pero del pan ajeno [46]. Brasa trae en su seno, la que cría hijo ajeno [46]. С другой стороны, то, что является враждебным и чужим может закалить человека, сделать его сильнее: $E l$ pan ajeno hace al hijo bueno [46].

Последняя из выделенных группа паремий (VI) имеет сему «не свое и экзотичное / желанное»: Gusta lo ajeno más por ajeno que por bueno [46]. La fruta más sabrosa es la del mercado ajeno [46]. Fruto del árbol ajeno, sale de balde y sabe bueno [46]. Hipócrates y galeno trajeron a mi casa el bien ajeno [46] / Abenruiz y Galileo traen a mi casa el bien ajeno [47] / Averroes y Galeno traem a mi casa el bien ajeno [47]. В данных пословицах речь идет не столько о материальных благах, которые желает получить человек, сколько о том, что, будучи незнакомыми и не своими, эти блага кажутся лучше, чем есть на самом деле.

Возвращаясь к семантической оппозиции ajeno - propio, скажем несколько слов о паремиях, в которых присутствует лишь один компонент из оппозиции - лексема propio, которую мы взяли в качестве опорного компонента для поиска корпуса паремий и определения их количества. Источником послужили те же ресурсы, что и для поиска паремий с опорным словом ајепо. Выяснилось, что количество искомых паремий значительно меньше (44) в сравнении с паремиями с опорным словом ајепо. Стоит отметить, что имена существительные, с которыми они согласуются, в основном отличаются от тех, что используются в паремиях со словом ajeno: Cada hombre construye su propio destino [46]. No limites a tus hijos a tu propio conocimiento [46]. Darle una sopa de su propio chocolate [46]. De ahora en adelante, yo seré mi propio comandante [46]. De su propio talento, ninguno hay descontento [46]. Casarse es poner una serpiente en el propio bolso [46].

Паремии со стержневым словом propio относятся практически ко всем видам паремий. Большая часть (21) выявленных паремий пересекается с паремиями со стержневым словом аjeno, хотя также поисковый запрос на лексему propio принес ряд паремий, в которых встречаются оба компонента семантической оппозиции, но которые не выдал запрос на слово ајеnо. Так, например, были выявлены пословицы El perro propio cuida mejor la casa que el ajeno [47]. No salgas de la propia casa, ni entres en la ajena, con la vejiga llena [47]. El plato de la mesa ajena se antoja mas que el propia [47]. Quien de 
bienes ajenos se llena, su propia bajel barrena [47]. Quien espera salud en muerte ajena, su propia vida condena [47].

Изучение паремий со стержневым словом propio принесло ещё один результат. Был выявлен вариант пословицы, в котором в семантической оппозиции слову propio выступает слово extraño синоним ajeno: El que a pueblo ajeno va a casar, o va engañado o va a engañar [47] / El que a pueblo extraño va a enamorar, va a que lo engañen o a engañar [46]. Поиск паремий с опорным словом extraño дал всего 7 паремий, таких как: Barca, juego у camino del extraño hacen amigo [47]. Si andas por camino extraño, no te alces mucho el sayo [47]. Rabo por rabo, más vale ir al propio que al extraño [46]. B них слово extraño выступает в значении полнозначного синонима слову ajeno: под camino del extraño понимается «дорога с чужбины (чужой земли)», под сатіпо extraño - «неизвестная, не своя, чужая дорога», фраза ir al extraño подразумевает «чужую собственность». Некоторые из паремий с опорным словом extraño имеют сходство с паремиями со словом ajeno: A cordero extraño no agasajes en tu rebaño [47] / A cordero extraño, no metas en tu rebaño [47] (refranes) - Carnero que se mete en rebaño ajeno, vuelve al suyo trasquilado [46] (proverbio). Трудно сказать, являются ли они трансформациями, или паремиями, принадлежащими к другому паремиологическому разряду, или дело в их географическом происхождении. Приведем еще один пример подобных паремий: Cada gallo canta en su gallinero, y el que es bueno, en el suyo y en el ajeno [46] / El gallo bueno, canta igual en su corral que en el ajeno [46] / Gallo bueno, tanto en su corral como en el ajeno [46] / Gallo que es bueno, lo mismo canta en su corral que en el ajeno [46]. - En corral extraño, las gallinas les pueden a los gallos [46]. Данные паремии, как нам кажется, не являются вариантами или трансформантами, поскольку выражают разные смыслы. Это подтверждает мысль о том, что паремии являются достаточно устойчивыми структурами, и замена составляющих их слов на синонимы происходит лишь в речи, в узусе.

В корпусе изучаемых паремий со стержневым словом ајепо было выявлено небольшое количество (18) предписывающих паремий с глаголами в повелительном наклонении. Четыре из них согласно классификации К.А. Крида Альварес и Х. Севилья Муньос [45] относятся к разряду proverbios и содержат глагол в отрицательной форме в повелительном наклонении: No cacarees en corral ajeno [46]. No pises nunca lo ajeno, ni las piezas, ni el terreno [46]. No críes hijo ajeno, no sabes si te saldrá bueno [46]. No salgas de la propia casa, ni entres en la ajena, con la vejiga llena [48]. Данные пословицы имеют ярко выраженную предписывающую функцию и сообщают о том, чего именно делать нельзя. Во всех содержится глагол во 2 лице ед. ч., что создает эффект персонального обращения к адресату инструкции.

В бо́льшем количестве паремий (11) глагол стоит в утвердительной форме императива также во 2 лице ед.ч. Эти паремии, судя по синтаксической структуре и наличию рифмы, относятся к разряду пословиц (refranes): Al juzgar un hecho ajeno, mete la mano en tu seno [46]. Escucha al agujero y oirás tu mal y del ajeno [44]. Lo mucho ajeno ten en poco, y lo poco tuyo, en mucho [46]. Fraile de buen seso, guarda lo suyo y guarda lo ajeno [46]. Cuando fueres a concejo, acuerda en lo tuyo y deja lo ajeno [47]. De lo propio, se da un puñado, de lo ajeno, llena el saco [46]. De lo ajeno, gastar sin miedo, de lo propio, poquito a poco [46]. Así usa lo tuyo, que no cures de lo ajeno [46]. Lo que no quieras que se sepa, ni en plaza, ni en barrio ajeno, tenlo siempre en tu seno [46]. Ama lo tuyo y respeta lo ajeno, que aquello es miel y esto veneno [46]. Compra con tu dinero, y no con el ajeno [46]. В испанистике ведутся дискуссии по поводу того, относить подобные высказывания к высказываниям с деонтической или аппелятивной модальностью. По мнению Ф.Х. Гранде Алиха, императивные конструкции различного вида, в том числе утвердительный императив с глаголом в форме 2 лица ед.ч., обладают аппелятивной модальностью, в то время как деонтической модальностью обладают только высказывания с глаголами, имеющими семантику долженствования и необходимости, такими как deber, tener que, haber que и др. Из всего корпуса изучаемых паремий только три отвечают данному требованию: El amo bueno no debe fiarse del ojo ajeno [46]. El asno bueno, no se debe fiar del ojo ajeno [48]. No hay que saludar con sombrero ajeno [46]. Они относятся к разряду пословиц (refranes), и в отличие от предыдущих, выражают четкую инструкцию к тому, как необходимо действовать в тех или иных обстоятельствах.

\section{Заключение}

Интерпретация ценностных установок помогает лучше понять отношение этноса к тому или иному явлению с синхронической позиции. Анализ корпуса испаноязычных паремий со стержневым словом ajeno показал, что испанские пословицы, раскрывающие отношение к чужому, являются достаточно многочисленными, по сравнению с паремиями, содержащими слово propio, которое является 
его антонимом. Таким образом, гораздо чаще испанские пословицы учат, как нужно относиться к чужому имуществу, проблемам, бедам, нежели к своим собственным. Чаще всего анализируемые пословицы имеют форму сентенции, реже - побуждения в форме грамматического императива. В пословицах со стержневым словом ајепо очень часто отражается отрицательное отношение к чужому имуществу, к другим людям, к их проблемам; гораздо реже отношение к чужому имеет нейтральную окраску и в исключительных случаях - положительную. Достаточно отчётливо прослеживается разделение паремий на те, в которых происходит оценка чужого материального имущества и те, в которых выражается отношение к нематериальным, абстрактным феноменам. В первом случае констатируется пагубность, тщетность обладания чужим имуществом, а также вполне естественное желание им обладать. Во втором случае выражается очевидное безразличие к тому, что нематериально и не связано отношениями посессивности с субъектом.

\section{СПИСОК ИСТОЧНИКОВ И ЛИТЕРАТУРЫ}

1. Алефиренко Н.Ф., Семененко Н.Н. Когнитивно-прагматическая природа паремии // Пословицы в фразеологическом поле: когнитивный, дискурсивный, сопоставительный аспекты. Монография. Владимир, Изд-во ВлГУ. 2017. с. 14-53

2. Алефиренко Н.Ф. Фразеологическое значение в свете когнитивной семиологии // Проблемы семантики языковых единиц в контексте культуры (лингвистический и лингвометодический аспекты): Международная научно-практическая конференция 17-19 марта 2006 г. М.: ООО «Издательство «Элпис», 2006. С.8-12.

3. Багаутдинова Г.А. Байрамова Л.К. Проблемы аксиологической фразеологии // Проблемы семантики языковых единиц в контексте культуры (лингвистический и лингвометодический аспекты): Международная научно-практическая конференция 17-19 марта 2006 г. М.: ООО «Издательство «Элпис», 2006. С. 12-15.

4. Благова Г.Ф. Пословица и жизнь: Личный фонд русских пословиц в историко-фольклористической ретроспективе. М.: 2000

5. Быкова А.С. Оценочная объективизация образа женщины в пословицах и афоризмах русского и английского языков. http://rospil.ru/russians/russians-13.htm (Дата доступа 18.01.2020)

6. Даль В.И. Пословицы русского народа. Т1. М., 1984.

7. Диас Ферреро А.М., Керо Хервилья Э.Ф. Анализ паремий, выражающих негативную оценку женщины в русском и португальском языках // Вестник Томского государственного университета. Филология. 2018. № 5. C. $42-55$

8. Егорова А.В. Имена живой и неживой природы в аксиологическом и концептологическом аспектах (на материале пословично-поговорочного фонда английского языка): автореф. дис. ... канд. филол. наук. Иваново, 2006.

9. Жуков В.П. Словарь русских пословиц и поговорок / сост. В. П. Жуков. Изд. 3-е, стереотип. Москва: Советская энциклопедия, 1966. 535 с.

10. Иванова Е. В. Пословичные картины мира (на материале английских и русских пословиц). СПб., 2002.

11. Ковшова М.Л. Семантика и прагматика фразеологизмов (Лингвокультурологический аспект): автореф. дис. ... доктора филол.наук. М.: 2009. 48 с.

12. Концептосфера русского языка: ключевые концепты и их репрезентация в языке и речи (на материале лексики, фразеологии и паремиологии) : словарь / под общ. ред. проф. Л.Г. Бабенко. М.: Изд. Центр «Азбуковник», 2017. $1020 \mathrm{c}$.

13. Кораблева Е.А. Фразеологизмы, выражающие чувства и эмоции человека с отрицательной коннотацией с компонентом «сердце», «душа» // Проблемы семантики языковых единиц в контексте культуры (лингвистический и лингвометодический аспекты): Международная научно-практическая конференция 17-19 марта 2006 г. М.: ООО «Издательство «Элпис», 2006. С. 440-444.

14. Медведева Т.С., Медведева Д.И. Репрезентация концепта гора в русской лингвокультуре и его аналогов в болгарской и сербской лингвокультурах // Вестник Удмуртского университета, серия История и филология. Т. 26, вып. 6, 2019. С. 933-941.

15. Мелерович А.М. О способах репрезентации фрагментов национальной языковой картины мира в словаре Х.Вальтера и В.М. Мокиенко «Антипословицы русского народа» // Слово в словаре и дискурсе: Сб. науч. ст. к 50-летию Харри Вальтера. М., 2006. С. 570-576.

16. Милютина М.Г. Субстантивация прилагательных в превосходной степени сравнения в современном русском языке // Вестник Удмуртского университета, серия История и филология. Т. 26, вып. 5, 2016. С. 21-28.

17. Миронова Г., Купцевич Е. Паремийный фонд национального языка как отражение кризисных явлений в обществе // Paremie narodů slovanskych. Ostrava, 2007. S. 45-62

18. Мокиенко В.М. Предисловие // Большой словарь русских пословиц (Около 70000 пословиц). Сост.: Мокиенко В.М., Никитина Т.Г., Николаева Е.К. М.: ОЛМА Медия Групп. 2010. с. 4-9. 
19. Мокиенко B.M. Современная паремиология (лингвистические аспекты) // MИPC. 2010. № 3 URL: https://cyberleninka.ru/article/n/sovremennaya-paremiologiya-lingvisticheskie-aspekty (дата обращения: 13.01.2020)

20. Никитина Т. Г. Психологический портрет диалектоносителя в пословицах и поговорках Псковской земли // Studia Slavica Savariensia. 1996. N 1-2. Р. 145-155.

21. Пермяков Г.Л. Основы структурной паремиологии. М.: Главная редакция восточной литературы издательства «Наука», 1988. 237 с. (24-29)

22. Семененко Н.Н. Когнитивно-прагматическая парадигма паремической семантики (на материале русского языка). Автореф. дисс. ... доктора филол. наук. Белгород, 2011. 46 с.

23. Сидоркова Г. Д. Прагматика паремий: пословицы и поговорки как речевое действие. Краснодар, 1999

24. Снегирев И.М. Русские в своих пословицах. Рассуждения и исследования об отечественных пословицах и поговорках. Изд. 2-е. М.: Книжный дом «ЛИБРОКОМ». 2012 - 184 с.

25. Тимофеев В. П. Фразеология диалектной личности. Шадринск, 2003.

26. Цзиньфэн Линь. Концепты [ТЕЛО], [ДУША], [ДУХ] в русской и китайской языковых картинах мира (антропологическая трихотомия в пословичной картине мира): дис. ... канд. филол. наук. Санкт-Петербург, 2018. $368 \mathrm{c}$.

27. Amali H, Ciroma Z., Bashir A. Idoma. Proverbial Names as a Vehicle of Expression: Asociolinguistic View // Proverbium, 36. The University of Vermont. 2019. pp. 57-74.

28. Čermák F. Lexical Foundation of Proverbs. Based on Data from English, German, French and Czech // Proverbs: Their Lexical and semantic Features. Burlington, Vermont. 2014. pp. 91-110.

29. Čermák F. Pragmatics of Proverbs: Basic Types of Evaluation // Proverbs: Their Lexical and semantic Features. Burlington, Vermont. 2014. pp. 147-155.

30. Corpus de Real Academia Española. URL: http://www.corpus.rae.es (дата обращения: 21.12.2019)

31. Doulaveras A. Wine in the Proverbial Discourse of the Greek People // Proverbium, 23. The University of Vermont. 2006. pp. 121-133.

32. Doyle Clay Charles. Doing Proverbs And Other Kinds of Folklore. Burlington, Vermont. 2012.346 pp.

33. Grande Alija F.J. Las modalidades de la enunciación. Tesis doctoral. León: Universidad de León, 1996.1129 p.

34. Haas Heather A. Proverb familiarity in the United States: cross-regional comparisons of the paremiological minimum // Journal of American Folklore. 2008.

35. Hulme, Edward F. Proverb Lore. Edited by W. Mieder. Burlington, Vermont. 2007. 270 pp.

36. Jaime Lorén José María de, Jaime Gómez José de. El queso en la refranística castellana // Proverbium, 25. The University of Vermont. 2008. pp. 159-178.

37. Konstantinova A. "Time's Up" When Enough is Enough: The Proverbial Voice of Social Change. Proverbium, 36. The University of Vermont. 2019. pp. 121-134

38. Kraller Anna-Lisa. "Resistance to Tyrants is Obedience to God". Theodore Parker's Proverbial Fight for the Ideal American Society. Burlington, Vermont. 2016. 221 pp.

39. Moliner M. Diccionario de uso del español. Madrid: Gredos, 1998 (электронный ресурс).

40. Petrova R. Truth in Anglo-American Proverbs // Proverbium, 36. The University of Vermont. 2019. pp. $277-340$.

41. Valdés, Ildefonso Pereda. Proverbios y refranes. De Salamón al Viejo Vizcacha. Universidad de la república. 1998. $119 \mathrm{pp}$

42. Mieder W. Origin of Proverbs // Introduction to Paremiology: A Comprehensive Guide to Proverb Studies. Edited by Hrisztalina Hrisztova-Gotthardt, Melita Aleksa Varga. Published by De Gruyter Open Ltd, Warsaw/Berlin. 2014 (электронное издание).

43. Mieder W. Historia y futuro de los refranes comunes en Europa. Paremia, 9: 2000. Madrid. Pp. 15-24.

44. Refranero Multilingüe de Centro Virtual Cervantes URL: https:/cvc.cervantes.es/lengua/refranero/Default.aspx (дата обращения: 21.12.2019)

45. Sevilla Muñoz J., Crida Álvarez C.A. Las paremias y su clasificación. Paremia, 22: 2013. p. 105-114

46. URL: https://www.buscapalabra.com/ (дата обрашения: 21.12.2019)

47. URL: http://www.martinezdecarnero.com/glossword/index.php (дата обращения: 21.12.2019)

48. URL: http://www.refranerocastellano.com/ (дата обращения: 21.12.2019)

49. URL: https://dle.rae.es/contenido/actualizaci\%C3\%B3n-2019 (дата обращения: 21.12.2019)

50. URL: https://servicios.elpais.com/diccionarios/sinonimos-antonimos/ajeno (дата обращения: 26.12.2019)

51. URL: https://www.sinonimosonline.com/ajeno/ (дата обращения: 26.12.2019)

Поступила в редакцию 05.04.2020

Меньшакова Надежда Николаевна, кандидат филологических наук, доцент

кафедры лингвистики и перевода факультета современных иностранных языков и литератур

Пермский государственный национальный исследовательский университет

614990, Россия, г. Пермь, ул. Букирева 15

E-mail: mnesperanza@mail.ru 


\title{
N.N. Menshakova SPANISH PAREMIAS WITH THE HEADWORD ‘AJENO’: LINGUOCULTURAL ASPECT
}

\author{
DOI: $10.35634 / 2412-9534-2020-30-6-976-987$
}

The article deals with linguocultural analysis of Spanish paremias with the headword ajeno. Due to their syntacticsemantic structure, proverbs are considered to be the most representative paremic genre in paremiology. Studying proverbs one can study ethnocultural originality of the language, pragmatic and functional potential of paremias in speech, the way of understanding reality and the way of forming cultural meaning of paremias. The Spanish paremias that are analyzed in the work as a rule belong to the category of proverbs. In the course of the analysis we considered compatibility of the lexeme 'ajeno' with the words that most often collocate with it. These words are nouns, verbs, and pronouns in the possessive case. The analysis revealed proverbs with binary opposition ajeno - propio, as well as proverbs in which the word ajeno comes into opposition with possessive pronouns or verbs in the form of the first person plural. The headword ajeno is most often found in proverbs than its synonyms, for example the word extraño. Variants of proverbs, their differences, the reasons for their existence are also analyzed. The logical and thematic analysis of the proverbs makes it possible to divide them into six groups according to the evaluation of other people or other people's property expressed in them. On this basis, conclusions are drawn about the linguistic and cultural features of paremias with the headword ajeno.

Keywords: paremiology, paremia, ajeno, Spanish, linguoculturology, phraseology, evaluation.

\section{REFERENCES}

1. Alefirenko N.F., Semenenko N.N. Kognitivno-pragmaticheskaya priroda paremii [Cognitive and pragmatic character of paroemias] // Poslovitsy v frazeologicheskom pole: kognitivnyy, diskursivnyy, sopostavitel'nyy aspekty [Proverbs in phraseology: cognitive, discursive and comparative aspects]. Vladimir, Russia: VlGU, 2017 (in Russian)

2. Alefirenko N.F. Frazeologicheskoe znachenie v svete kognitivnoy semio-logii [Phraseological knowledge in the light of cognitive semiology] // Problemy semantiki yazykovykh edinits v kontekste kul'tury (lingvisticheskiy i lingvometodicheskiy aspekty) [Problems of semantics of language units in cultural context (linguistic and linguometodological aspect]. Moscow, Russia: Elpis, 2006 (in Russian)

3. Bagautdinova G.A. Bayramova L.K. Problemy aksiologicheskoy frazeologii [Problems of axiological phraseology] // Problemy semantiki yazykovykh edinits v kontekste kul'tury (lingvisticheskiy i lingvometodicheskiy aspekty) [Problems of semantics of language units in cultural context (linguistic and linguometodological aspect]. Moscow, Russia: Elpis, 2006 (in Russian)

4. Blagova G.F. Poslovitsa i zhizn': Lichnyy fond russkikh poslovits v istoriko-fol'kloristicheskoy retrospektive [Proverb and life: private corpus of Russian proverbs in historical and folkloric retrospective]. Moscow, Russia, 2000 (in Russian)

5. Bykova A. S. Otsenochnaya ob'ektivizatsiya obraza zhenshchiny $\mathrm{v}$ poslovitsakh $\mathrm{i}$ aforizmakh russkogo $\mathrm{i}$ angliyskogo yazykov [Evaluative objectivation of the image of woman in proverbs and aphorisms of Russian and English]. Retrieved from: http://rospil.ru/russians/russians-13.htm (in Russian)

6. Dal' V.I. Poslovitsy russkogo naroda [Proverbs of the Russian people]. Volume 1. Moscow, Russia, 1984 (in Russian)

7. Diaz Ferrero A.M., Kero Jervilla E.F. Analiz paremiy, vyrazhayushchikh negativnuyu otsenku zhenshchiny v russkom i portugal'skom yazykakh [Analysis of paroemias expressing negative evaluation of woman in Russian and Portuguese]. Tomsk, Russia: Tomsk State University Bulletin. № 5, 2018 (in Russian)

8. Egorova A.V. Imena zhivoy i nezhivoy prirody v aksiologicheskom i kontseptologicheskom aspektakh (na materiale poslovichno-pogovorochnogo fonda angliyskogo yazyka) [Names of living and not non-living objects in axiological and conceptual aspect (on the material of proverbs and sayings of the English language)] - PhD Thesis. Ivanovo, Russia, 2006 (in Russian)

9. Zhukov V.P. Slovar' russkikh poslovits i pogovorok [Dicctionary of Russian proverbs and sayings] / sost. V.P. Zhukov. Izd. 3-e, stereotip. Moskva: Sovetskaya entsiklopediya, 1966. $535 \mathrm{p}$

10. Ivanova E.V. Poslovichnye kartiny mira (na materiale angliyskikh i russkikh poslovits) [Proverbial picture of the world (on the material of English and Russian proverbs]. Saint-Petersburg, Russia, 2002 (in Russian)

11. Kovshova M.L. Semantika i pragmatika frazeologizmov (Lingvokul'turologicheskiy aspekt) [Semantics and pragmatics of phraseology (Linguacultural aspect)] - Grand PhD. Moscow, Russia, 2009 (in Russian)

12. Kontseptosfera russkogo yazyka: klyuchevye kontsepty i ikh reprezentatsiya v yazyke i rechi (na materiale leksiki, frazeologii i paremiologii) : slovar' [Conceptual sphere of the Russian Language: Key concepts and their representation in language and speech (on the material of vocabulary, phraseology and paroemiology. Dictionary] - edited by Prof. L.G. Babenko. Moscow, Russia: Azbukovnik, 2017 (in Russian)

13. Korableva E.A. Frazeologizmy, vyrazhayushchie chuvstva i emotsii cheloveka s otritsatel'noy konnotatsiey s komponentom «serdtse», «dusha» [Phraseological units representing people's feelings and emotions with negative 
connotation with a component "heart", "soul"] - Problemy semantiki yazykovykh edinits v kontekste kul'tury (lingvisticheskiy i lingvometodicheskiy aspekty) [Problems of semantics of language units in cultural context (linguistic and linguometodological aspect]. - International conference. Moscow, Russia: Elpis, 2006 (in Russian)

14. Medvedeva T.S., Medvedeva D.I. Reprezentatsiya kontsepta gora v russkoy lingvokul'ture i ego analogov $\mathrm{v}$ bolgarskoy i serbskoy lingvokul'turakh [Representation of the concept gora (mountain) in the russian linguistic culture and its analogues in the bulgarian and serbian linguistic cultures] // Vestnik Udmurtskogo universiteta, seriya Istoriya i filologiya. Vol. 26, issue 6, 2019. P. 933-941.

15. Melerovich A.M. O sposobakh reprezentatsii fragmentov natsional'noy yazykovoy kartiny mira $\mathrm{v}$ slovare Kh. Val'tera i V.M. Mokienko «Antiposlovitsy russkogo naroda» [About the ways of representing parts of the linguistic picture of the world in the Dictionary of Anti-proverbs of the Russian people by H. Walter and V. M. Mokienko] Slovo v slovare i diskurse: Sb. nauch. st. k 50-letiyu Kharri Val'tera [Word in a Dictionary and in Discourse: collection of articles by the $50^{\text {th }}$ anniversary of H. Walter]. Moscow, Russia, 2006 (in Russian)

16. Milyutina M.G. Substantivatsiya prilagatel'nykh v prevoskhodnoy stepeni sravneniya v sovremennom russkom yazyke [Substantivation of adjectives in the superlative degree in the modern russian language] // Vestnik Udmurtskogo universiteta, seriya Istoriya i filologiya. Vol. 26, issue 5, 2016. P. 21-28

17. Mironova G., Kuptsevich E. Paremiynyy fond natsional'nogo yazyka kak otrazhenie krizisnykh yavleniy v obshchestve [Paremiological fund of national language as a reflection of crisis in society] - Paremie narodů slovanskych [Slavic paroemias]. Ostrava, Czech Republic, 2007 (in Russian)

18. Mokienko V.M. Predislovie. Bol'shoy slovar' russkikh poslovits (Okolo 70000 poslovits) [Foreword to Big Diccionary of Russian proverbs (about 70000 words)]. Compiled by Mokienko V.M., Nikitina T.G., Nikolaeva E.K. Moscow, Russia: OLMA Mediya Grupp, 2010 (in Russian)

19. Mokienko V.M. (2010) Sovremennaya paremiologiya (lingvisticheskie aspekty) [Modern Paremiology (linguistic aspects)]. Retrieved from: https://cyberleninka.ru/article/n/sovremennaya-paremiologiya-lingvisticheskie-aspekty (in Russian)

20. Nikitina T.G. Psikhologicheskiy portret dialektonositelya v poslovitsakh i pogovorkakh Pskovskoy zemli [Psychological portrait of a speaker of the dialect in proverbs and sayings of Pskov Region] - Studia Slavica Savariensia. Hungary. №1-2, 1996 (in Russian)

21. Permyakov G.L. Osnovy strukturnoy paremiologii [Basic principles of structural paremiology]. Moscow, Russia: Nauka, 1988 (in Russian)

22. Semenenko N.N. Kognitivno-pragmaticheskaya paradigma paremicheskoy semantiki (na materiale russkogo yazyka) [Cognitive and pragmatic paradigm of paremiological semantics (in the Russian Language) - Grand PhD Thesis. Belgorod, Russia, 2011 (in Russian)

23. Sidorkova G. D. Pragmatika paremiy: poslovitsy i pogovorki kak rechevoe deystvie [Pragmatics of paroemias: proverbs and sayings as discursive action]. Krasnodar, Russia, 1999 (in Russian)

24. Snegirev I.M. Russkie v svoikh poslovitsakh. Rassuzhdeniya i issledovaniya ob otechestvennykh poslovitsakh i pogovorkakh [Russian people in their proverbs. Reasoning and study of proverbs and sayings if Russian]. $2^{\text {nd }}$ edition. Moscow, Russia: Knizhnyy dom LIBROKOM, 2012 (in Russian)

25. Timofeev V. P. Frazeologiya dialektnoy lichnosti [Phraseology of a person speaking dialectal language]. Shadrinsk, Russia, 2003 (in Russian)

26. Tszin Fen Lin Kontsepty [TELO], [DUSHA], [DUKH] v russkoy i kitayskoy yazykovykh kartinakh mira (antropologicheskaya trikhotomiya v poslovichnoy kartine mira) [Concepts 'Body', 'Soul", "Spirit" in Russian and Chinese linguistic pictures of the world (anthropological trichotomy in Proverbial picture of the world] - PhD Thesis. Saint Petersburg, Russia, 2018. (in Russian).

27. Amali H, Ciroma Z., Bashir A. Idoma. (2019). Proverbial Names as a Vehicle of Expression: Asociolinguistic View. Proverbium, 36. The University of Vermont. pp. 57-74. (In English).

28. Čermák F. (2014). Lexical Foundation of Proverbs. Based on Data from English, German, French and Czech. Proverbs: Their Lexical and semantic Features. Burlington, Vermont. pp. 91-110. (In English).

29. Čermák F. (2014). Pragmatics of Proverbs: Basic Types of Evaluation // Proverbs: Their Lexical and semantic Features. Burlington, Vermont. pp. 147-155. (In English).

30. Corpus de Real Academia Española. Retrieved from: URL: http://www.corpus.rae.es (date of retrieving: 21.12.2019). (In Spanish).

31. Doulaveras A. Wine in the Proverbial Discourse of the Greek People // Proverbium, 23. The University of Vermont. 2006. pp. 121- 133 (In English).

32. Doyle Clay Charles.. Doing Proverbs And Other Kinds of Folklore. Burlington, Vermont. 2012.346 pp. (In English).

33. Grande Alija F.J. Las modalidades de la enunciación. Tesis doctoral. León: Universidad de León, 1996.1129 p. (In Spanish).

34. Haas Heather A. Proverb familiarity in the United States: cross-regional comparisons of the paremiological minimum // Journal of American Folklore. 2008. (In English).

35. Hulme, Edward F.. Proverb Lore. Edited by W. Mieder. Burlington, Vermont. 2007. 270 pp. (In English). 
36. Jaime Lorén José María de, Jaime Gómez José de. El queso en la refranística castellana. Proverbium, 25. The University of Vermont, 2008 (in Spanish). (In Spanish).

37. Konstantinova A. "Time's Up" When Enough is Enough: The Proverbial Voice of Social Change. Proverbium, 36. The University of Vermont. 2019. (In English).

38. Kraller Anna-Lisa. "Resistance to Tyrants is Obedience to God". Theodore Parker's Proverbial Fight for the Ideal American Society. Burlington, Vermont. 2016. (In English).

39. Moliner M. Diccionario de uso del español. Madrid: Gredos, 1998 (e-book). (In Spanish).

40. Petrova R. Truth in Anglo-American Proverbs. Proverbium, 36. The University of Vermont. 2019. (In English).

41. Valdés, Ildefonso Pereda. Proverbios y refranes. De Salamón al Viejo Vizcacha. Universidad de la república. 1998. 119 pp. (In Spanish).

42. Mieder W. Origin of Proverbs // Introduction to Paremiology: A Comprehensive Guide to Proverb Studies. Edited by Hrisztalina Hrisztova-Gotthardt, Melita Aleksa Varga. Published by De Gruyter Open Ltd, Warsaw/Berlin. 2014. (E-book). (In English).

43. Mieder W. Historia y futuro de los refranes comunes en Europa. Paremia, 9: Madrid. 2000. Pp. 15-24. (In Spanish).

44. Refranero Multilingüe de Centro Virtual Cervantes Retrieved from: https://cvc.cervantes.es/lengua/refranero/ Default.aspx (date of retrieving: 21.12.2019). (In Spanish).

45. Sevilla Muñoz J., Crida Álvarez C.A. Las paremias y su clasificación. Paremia, 22. 2013 (in Spanish).

46. URL: https://www.buscapalabra.com/ (date of retrieving: 21.12.2019). (in Spanish).

47. URL: http://www.martinezdecarnero.com/glossword/index.php (date of retrieving: 21.12.2019). (in Spanish).

48. URL: http://www.refranerocastellano.com/ (date of retrieving: 21.12.2019). (in Spanish).

49. URL: https://dle.rae.es/contenido/actualizaci\%C3\%B3n-2019 (date of retrieving: 21.12.2019). (in Spanish).

50. URL: https://servicios.elpais.com/diccionarios/sinonimos-antonimos/ajeno (date of retrieving: 26.12.2019). (in Spanish).

51. URL: https://www.sinonimosonline.com/ajeno/ (date of retrieving: 26.12.2019). (in Spanish).

Received 05.04.2020

Menshakova N.N., Candidate of Philology, Associate Professor at Department of Linguistics and Translation, Faculty of Foreign Languages and Literatures

Perm State University

Bukireva st, 15, Perm, Russia 614990

E-mail: mnesperanza@mail.ru 